\title{
IATURE LIBRARY
}

\section{ATCHING BIRDS: N INTRODUCTION TO
RNITHOLOGY}

DGER F. PASQUIER. 1977. bughton Mifflin Co., Boston. 301 $\$ 10.00$.

Have you ever wondered what ves a feather its colour... what is e meaning of a bird's song? ... ow a bird navigates?

Watching Birds will give you the swers. This very readable book as written not simply to answer lestions on birds but also to mulate the bird watcher to ask and try to answer his own questions. isquier wrote Watching Birds for e bird watcher and the environentalist as a guide to the main pics of ornithology, such as origin id evolution, flight, food and eding habits, voice, breeding cycle, gration, winter habits, distribution. also explains how and why birds studied, the role that the amateur ays in bird study, how birds can be racted and protected.

The book has an introduction by gger Tory Peterson, 112 attractive ack-and-white illustrations by argaret La Farge, a suggested ading list of 101 books and an apndix listing ornithological and nservation organizations, their agazines and journals.

Pasquier gives many interesting eces of information. We learn, for ample, that birds use tools - the podpecker Finch of the Galapagos es a thorn to probe for insects on es, while the Egyptian Vulture es stones, throw with its bill, to break open Ostrich eggs. Two unusual incubating techniques are treated. The hole-nesting hornbills of Africa and south Asia plaster mud over the entrance sealing in the female with her eggs; the male then feeds her through a hole in the mud. A second curious behaviour is that of the male megapodes of Australia, which spend the entire year tending a nest pile in which several females lay eggs. The male then buries them and adjusts the amount of sand, warm volcanic ash or rotting vegetation on the nest. Young megapodes hatch fully feathered and capable of flight. Of perennial interest is the question of bird navigation. How is one to explain for example, that a Manx Shearwater released at Boston, 3,050 miles from its home in Wales, was back at its burrow in $12 \frac{1}{2}$ days.

Watching Birds is a book for the beginning bird watcher, to be used as a companion to the field guides, a book that ". . . will show you ways to consider your own observations and will encourage you to investigate further the life of birds in the environment we all share." - Reviewed by B. W. Johns, 51 Beurling Cresc., Saskatoon, Saskatchewan, S7H 4 V6.

\section{RARE VASCULAR PLANTS OF SASKATCHEWAN}

The Rare Vascular Plants of Saskatchewan has just been published by the National Museum of Natural Sciences as one of its "Syllogeus Series" on the rare plants 